\title{
К ЛИТОЛОГИЧЕСКОЙ ХАРАКТЕРИСТИКЕ ПЯРНУСКОГО ГОРИЗОНТА В ОКРЕСТНОСТЯХ МУСТВЭЭ - ПАЛА ЭСТОНСКОЙ ССР
}

Совсем недавно существовало мнение о довольно ограниченном распространении в Эстонской ССР наиболее древних отложений среднего девона - песчаников пярнуского горизонта. Так, В. Селиванова и О. Элькин (1956) отмечали, что к востоку от г. Тарту пярнуский горизонт полностью отсутствует.

В ходе проведения съемочных работ, выполненных работниками Геологического управления Эстонской ССР (К. Каяком, авторами настоящей статьи и др.), было установлено наличие отложений пярнуского горизонта и в Восточной Эстонии. Изученный авторами керновый материал буровых скважин, пробуренных на западном побережье оз. Пейпси (Чудское), и послужил материалом для настоящей статьи.

Отложения пярнуского горизонта вскрыты на рассматриваемой территории 11 буровыми скважинами (рис. 1). Кроме того, они были вскрыты рядом буровых скважин в юго-восточной части Эстонии.

В Восточной Эстонии описываемые отложения залегают на сильно размытом ложе ордовикских и силурийских пород. Следуя с северовостока на юго-запад, можно проследить залегание отложений пярнуского горизонта на все более молодых породах ордовикско-силурийской толщи (от пиргуского до адавереского горизонта включительно).

Перекрываются отложения пярнуского горизонта более молодыми образованиями среднего девона - наровским и затем тартуским горизонтами. Выходы пярнуского горизонта под четвертичные отложения приурочены к бортам древних погребенных долин (рис. 2).

На рассматриваемой территории хорошо прослеживаются две пачки пярнуского горизонта, выделенные К. Орвику (Orviku, 1930) под названиями ториских и таммеских песчаников.

Рис. 1. Схема распространения выходов коренных пород в окрестностях Муствээ-Пала:

1 - буровые скважины, вскрывшие отложения пярнуского горизонта; 2 - выход пярнуского горизонта под четвертичные отложения; $\mathrm{O}_{3}-$ верхний ордовнк. $\mathrm{S}_{1}-$ нижний силур, $\mathrm{D}_{2} \mathrm{pr}$ - пярнуский горизонт, $\mathrm{D}_{2} \mathrm{nr}$ - наровскнй горнзонт, $\mathrm{D}_{2} \mathrm{tr}$ - старооскольский горнзонт.

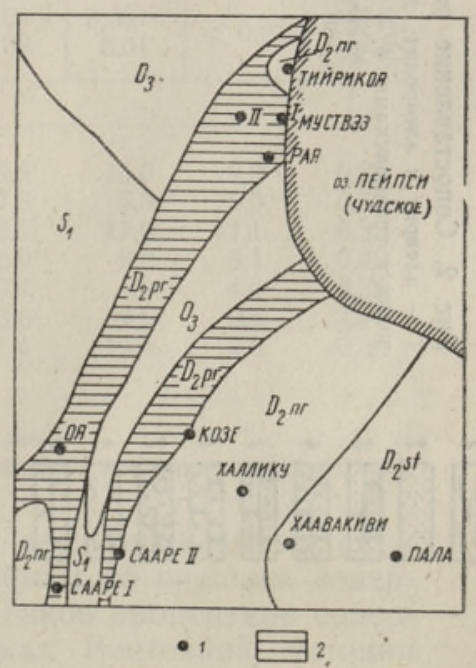




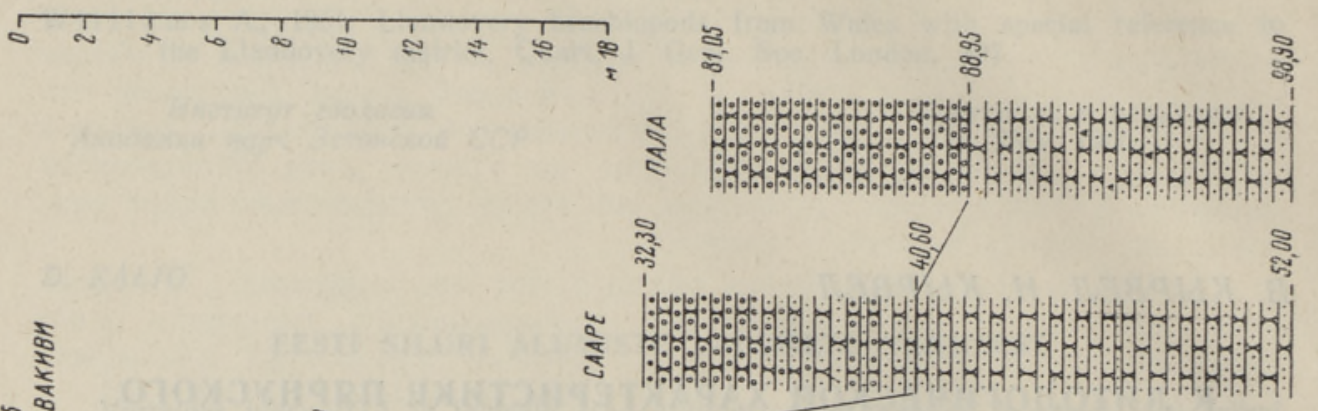

곤

कุ

용

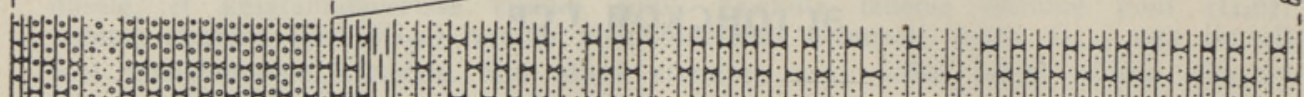

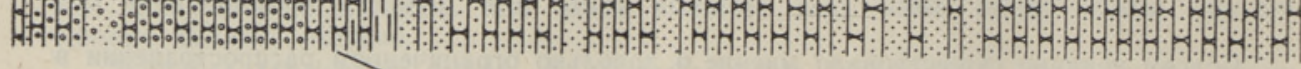
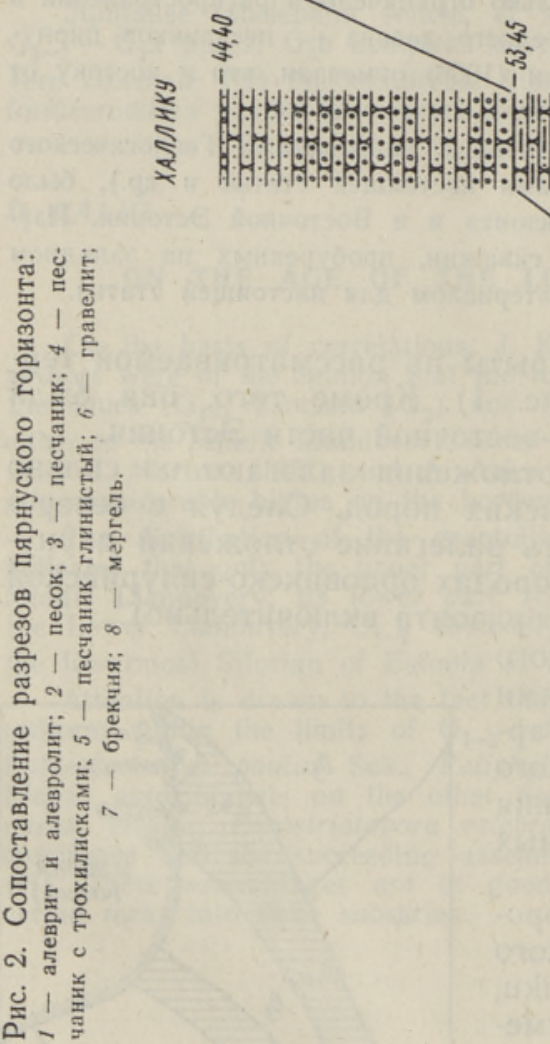

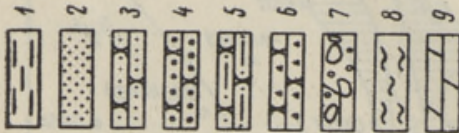
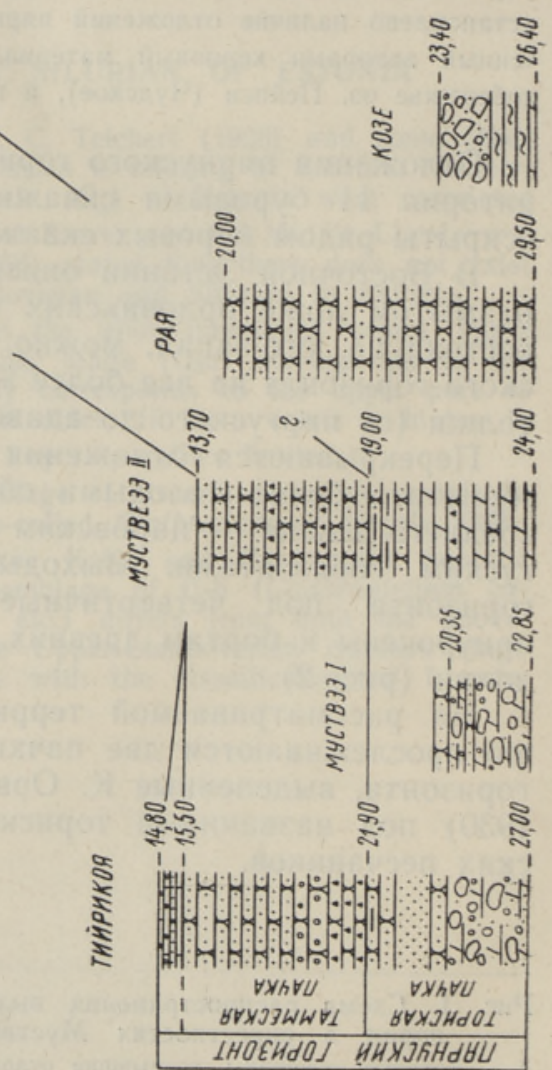
Ториская пачка ( $\left.\mathrm{D}_{2} \mathrm{pr} \mathrm{Tr}\right)$. ПЛесчаники ториской пачки широко распространены на всей рассматриваемой территории. В основании песчаника в Восточной Эстонии залегают базальный конгломерат и брекчия. Этот базальный слой пярнуского горизонта вскрыт скважинами Тийрикоя, Муствээ I, Козе и рядом скважин в Юго-Восточной Эстонии (Ныва, Лаэва, Каагвере - см. К. Каяк, 1962). Он представлен полуокатанными и неокатанными обломками доломитов и известняков подстила!щих пород. Встречаются обломки переотложенных остатков кораллов, брахиопод, строматопор и мшанок силурийского и ордовикского возраста. Размер обломков - от 0,5 до 2 и более см. Цементирующим материалом является карбонат магния и кальция. Окраска базального слоя преимущественно светлая: светло-серая и желтовато-серая. Мощность слоя в скважине Тийрикоя 2,55 м. В скважине Козе разрез пярнуского горизонта начинается пестроцветными доломитами $(0,3 \boldsymbol{s})$, над которыми залегает доломитовый мергель $(1,4$ м $)$, перекрываемый осадочной брекчией мощностью 1,3 м.

Залегающие на базальном слое песчаники и пески имеют преимущественно светлую окраску: почти белую, розовато-серую, зеленоватосерую и лишь изредка (в южных скважинах) - фиолетово-серую. По составу песчаники кварцевые, мусковито-кварцевые и полевошпатокварцевые. Преобладают мелкозернистые, в основном слюдистые песчаники. Степень цементации почти исключительно очень слабая. Цементом служит глинистое вещество, реже - карбонат магния и кальция (в плотных прослоях). Наблюдается косая слонстость типа диагональной, иногда тонковолнистая.

С целью получения минералого-гранулометрической характеристики ториских песчаников в районе западного побережья оз. Пейпси было произведено опробование скважины Сааре II (см. рис. 1) в интервале 41,5-52,0 м. Из этого интервала было отобрано 7 проб, анализы которых выполнены в лаборатории Тартуского государственного университета Х. Вийдингом. Результаты анализов приведены в табл. 1, 2 и 5.

Таблища 1

Гранулометрический состав ториских песчаников скв. Сааре

\begin{tabular}{|c|c|c|c|c|c|c|c|c|c|}
\hline \multirow{3}{*}{$\begin{array}{c}\text { № } \\
\text { мробы }\end{array}$} & \multirow{3}{*}{$\begin{array}{c}\text { Ннтервал } \\
\text { опробова- } \\
\text { ния, } м\end{array}$} & \multicolumn{4}{|c|}{$\mathrm{P}$ a $3 \mathrm{~m} \mathrm{ep}$} & 3 е рен н, & & \multirow[b]{2}{*}{$<0,01$} & \multirow{2}{*}{ 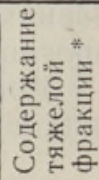 } \\
\hline & & $>1$ & $1-0,5$ & $\frac{0,5}{0,25}$ & $\begin{array}{r}0,25- \\
0,10\end{array}$ & $\frac{0,10}{0,06}$ & $\begin{array}{c}0,06-01 \\
0,01\end{array}$ & & \\
\hline & & \multicolumn{8}{|c|}{$\%$} \\
\hline $\begin{array}{l}7 \\
6 \\
5 \\
4 \\
3 \\
2 \\
1\end{array}$ & $\begin{array}{l}41,5-41,6 \\
42,6-43,1 \\
46,0-46,1 \\
48,0-48,2 \\
48,6-48,8 \\
49,5-49,6 \\
50,0-52,0\end{array}$ & $\begin{array}{l}\overline{0,1} \\
0,6 \\
0,7 \\
\overline{0,4} \\
2,5 * *\end{array}$ & $\begin{array}{l}1,0 \\
0,3 \\
0,7 \\
1,2 \\
0,4 \\
1,3 \\
0,4\end{array}$ & $\begin{array}{r}20,0 \\
1,5 \\
1,2 \\
5,6 \\
3,7 \\
2,5 \\
26,0\end{array}$ & $\begin{array}{l}39,2 \\
60,0 \\
16,3 \\
52,5 \\
37,7 \\
54,1 \\
26,2\end{array}$ & $\begin{array}{l}15,6 \\
27,6 \\
52,2 \\
30,9 \\
49,4 \\
33,6 \\
21,4\end{array}$ & $\begin{array}{r}15,0 \\
5,5 \\
17,9 \\
6,0 \\
4,8 \\
4,5 \\
19,5\end{array}$ & $\begin{array}{r}9,2 \\
5,0 \\
11,1 \\
3,1 \\
4,0 \\
3,6 \\
4,0\end{array}$ & $\begin{array}{l}0,30 \\
0,66 \\
0,32 \\
0,42 \\
0,36 \\
0,24 \\
0,36\end{array}$ \\
\hline
\end{tabular}

* Тяжелая фракция выделена из фракции $0,1-0,06$ мм.

** Зерна представлены в основном в виде агрегатов (сцементированных зерен).

Как видно из названных таблиц, ториские песчаники относятся к олигомиктовым кварце-полевошпатовым песчаникам со средним содержанием кварца $86 \%$ и полевых шпатов $10,6 \%$. Такое процентное содержание легких минералов в ториских песчаниках Восточной Эстонии 
соответствует минералогическому составу этих же песчаников в западғых и южных районах республики (Вийдинг, 1962; Татmе, 1960). В тяжелой фракции ториских песчаников преобладает гранат, составляющий в среднем $60 \%$. Циркон, монацит и ксенотим, вместе взятые, составляют $25 \%$, турмалин -12 , апатит -5 и рутил $-1 \%$. Остальные минералы встречаются в незначительных количествах.

В разрезах скважин Халлику и Хаавакиви в верхней части ториской пачки прослеживаются прослои алевритов и алевролитов мощностью до 3 м. Алевролиты песчаные, слюдистые, тонкослоистые, серого цвета с зеленоватым оттенком. Нередко они переходят в глинистый песчаник.

Таблица 2

Минералогический состав тяжелой фракции ториских песчаников скв. Сааре

\begin{tabular}{|c|c|c|c|c|c|c|c|c|c|c|c|c|c|c|c|}
\hline \multirow{2}{*}{$\begin{array}{l}\overline{3} \\
\frac{0}{0} \\
\text { 을 }\end{array}$} & 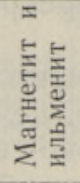 & 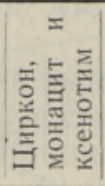 & 氞 & 豆 & 点 & ต & 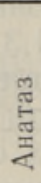 & 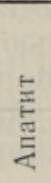 & 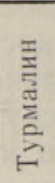 & 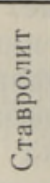 & 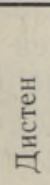 & 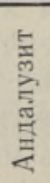 & $\frac{5}{\frac{5}{1}}$ & 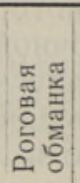 & $\frac{\text { 홍 }}{\stackrel{0}{0}}$ \\
\hline & \multicolumn{15}{|c|}{$\%$} \\
\hline
\end{tabular}

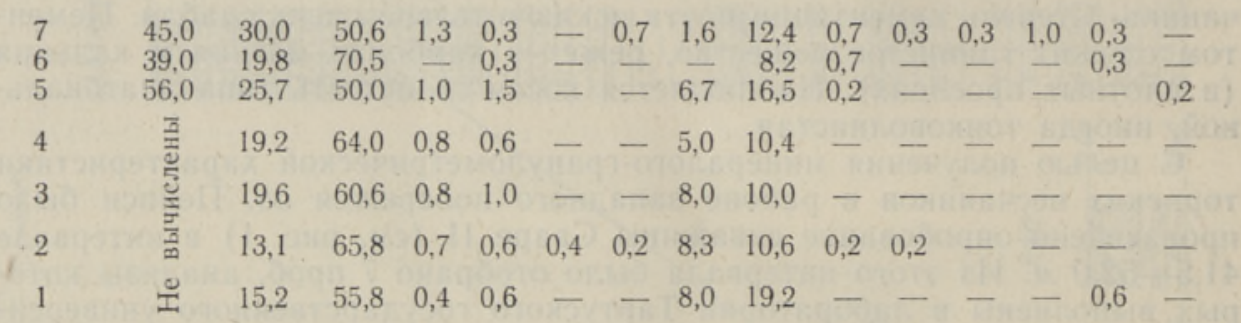

Песчаники и пески ториской пачки в указанных разрезах характеризуются обилием чешуек мусковита по всему разрезу и повышенной глинистостью в кровле пачки.

В разрезе скважины Муствээ II ториская пачка представлена в основном скрытокристаллическими доломитами, местами глинистыми с прослоями песчаника и гравелита.

Мощность отложений ториской пачки колеблется в довольно больших пределах. Она составляет (в метрах):

$\begin{array}{llll}\text { Тийрикоя } & -5,1 & \text { Хаавакиви } & -29,2 \\ \text { Муствээ II }-5,0 & \text { Сааре II } & -11,4 \\ \text { Халлику } & -22,55 & \text { Пала } & -9,95 .\end{array}$

Таким образом, наблюдается увеличение мощности в южном направлении и быстрое уменьшение ее как в северном, так и в восточном направлениях.

Tаммеская пачка ( $\left.\mathrm{D}_{2} \mathrm{pr} \mathrm{Tm}\right)$, представлена преимущественно песчаниками и алевролитами. В некоторых скважинах (Тийрикоя) в осноьании таммеской пачки залегает слой гравелитового песчаника серого и розовато-серого цвета. Песчаники и алевролиты характеризуются неравномерно зернистой структурой, средней степенью цементации, наличием многочисленных мелких (2-10 мм) слабо окатанных и неокатанных обломков глинистого известняка светлого желтовато-серого цвета.

Порода содержит заметное количество $(\sim 10 \%)$ трохилисков, достигающих в диаметре 0,4 мм. Некоторые из них имеют концентрическиячеистое строение, другие же представляют собой бесструктурные 
Гранулометрический состав таммеских песчаников скв. Сааре

\begin{tabular}{|c|c|c|c|c|c|c|c|c|c|}
\hline \multirow{3}{*}{$\frac{\text { № }}{\text { пробы }}$} & \multirow{3}{*}{$\begin{array}{c}\text { Интервал } \\
\text { опробова- } \\
\text { ния, } M\end{array}$} & \multicolumn{6}{|c|}{ Р а 3 м е $з$ е рен, $м \mu$} & \multirow[b]{2}{*}{$<0,01$} & \multirow{2}{*}{ 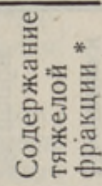 } \\
\hline & & $>1$ & $1-0,5$ & $\begin{array}{l}0,5- \\
0,25\end{array}$ & $\begin{array}{l}0,25- \\
0,10\end{array}$ & $\begin{array}{l}0,10- \\
0,06\end{array}$ & $\begin{array}{l}0,06- \\
0,01\end{array}$ & & \\
\hline & & \multicolumn{8}{|c|}{$\%$} \\
\hline $\begin{array}{r}14 \\
13 \\
12 \\
11 \\
10 \\
9 \\
8\end{array}$ & $\begin{array}{l}34,2-34,5 \\
34,8-34,9 \\
35,5-35,6 \\
36,7-36,9 \\
38,4-38,5 \\
39,0-39,1 \\
40,5-40,6\end{array}$ & $\begin{array}{l}\overline{-} \\
0,2 \\
\overline{0,2} \\
0,1 \\
2,0\end{array}$ & $\begin{array}{l}1,4 \\
0,2 \\
0,8 \\
0,6 \\
0,3 \\
1,3 \\
2,8\end{array}$ & $\begin{array}{l}4,1 \\
3,7 \\
4,7 \\
5,2 \\
0,3 \\
6,3 \\
5,2\end{array}$ & $\begin{array}{l}55,6 \\
66,0 \\
57,8 \\
65,0 \\
31,4 \\
47,4 \\
24,0\end{array}$ & $\begin{array}{l}27,2 \\
18,0 \\
21,8 \\
14,2 \\
34,9 \\
27,5 \\
34,0\end{array}$ & $\begin{array}{r}6,2 \\
6,1 \\
9,8 \\
5,0 \\
19,6 \\
9,8 \\
17,2\end{array}$ & $\begin{array}{r}5,5 \\
6,0 \\
4,9 \\
10,0 \\
12,8 \\
7,6 \\
14,8\end{array}$ & $\begin{array}{l}0,30 \\
0,50 \\
0,68 \\
0,52 \\
0,20 \\
0,34 \\
0,46\end{array}$ \\
\hline
\end{tabular}

* Тяжелая фракция выделена из фракцин 0,1-0,06 мм.

сгустковые, карбонатные образования. Наличие трохилисков служит характерным признаком для песчаников таммеской пачки.

Залегающие выше песчанистые породы характеризуются белой, светло-серой окраской, иногда с зеленоватым оттенком. Песчаники главным образом мелкозернистые, реже среднезернистые. Количество цемента в песчаниках обычно невелико $(\sim 20 \%)$. Цемент глинистокарбонатный. Степень цементации различная: наряду с рыхлыми и несцементированными песками встречаются прослои очень плотных песчаников. Характерна косая слоистость типа диагональной, реже песчаники горизонтально-слоистые.

Минералого-гранулометрическая характеристика таммеских песчаников приведена в табл. 3,4 и 5.

Таблица 4

Минералогический состав тяжелой фракции таммеских песчаников скв. Сааре

\begin{tabular}{|c|c|c|c|c|c|c|c|c|c|c|c|c|c|c|}
\hline $\begin{array}{l}\vec{A} \\
\vdots \\
\vdots\end{array}$ & 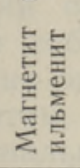 & 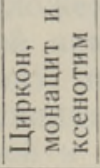 & 点 & $\stackrel{\Xi}{\stackrel{E}{E}}$ & 章 & 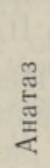 & 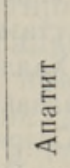 & 昱 & 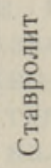 & 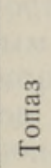 & 埡 & $\frac{5}{2}$ & 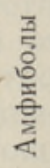 & 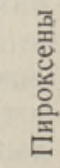 \\
\hline z & \multicolumn{14}{|c|}{$\%$} \\
\hline 14 & 32,5 & 13,4 & 76,5 & 1,7 & - & - & 1,5 & 6,8 & - & - & 0,2 & - & - & - \\
\hline 13 & 38,0 & 19,4 & 69,4 & 1,2 & 0,4 & - & 4,2 & 5,8 & - & - & 0,4 & 一 & - & 0,2 \\
\hline 12 & 35,8 & 18,0 & 70,4 & 0,6 & 0,4 & 0,2 & 4,2 & 6,4 & - & - & - & - & - & 0,2 \\
\hline 11 & 39,5 & 19,8 & 66,4 & 1,6 & 0,4 & - & 6,4 & 10,4 & 0,2 & 0,2 & 0,4 & 0,2 & - & - \\
\hline 10 & 43,0 & 10,6 & 33,6 & 1,1 & - & 0,6 & 25,2 & 26,4 & - & - & 1,7 & - & 0,5 & - \\
\hline 9 & 37,0 & 18,0 & 57,6 & 1,2 & 0,4 & - & 10,4 & 11,6 & 0,4 & - & 0,4 & - & 0,2 & - \\
\hline 8 & 30,5 & 8,0 & 83,4 & 0,4 & 0,4 & - & 3,8 & 4,0 & - & - & - & - & - & - \\
\hline
\end{tabular}

Таммеские песчаники, как и песчаники ториской пачки, относятся к олигомиктовым кварцево-полевошпатовым песчаникам. В отличие от ториских песчаников среднее процентное содержание кварца таммеских гесчаников уменьшается до $80 \%$ при увеличении содержания полевых шпатов до $14 \%$.

В составе тяжелой фракции имеются некоторые отличия от нижележащих ториских песчаников. Среднее содержание турмалина, циркона, монашита и ксенотима здесь уменьшается за счет увеличения содержания апатита и титанита. 
Таблица 5

Среднее содержание легкой фракции ториских и таммеских песчаников скв. Сааре

\begin{tabular}{|c|c|c|c|c|c|}
\hline 产 & ठే & Кварц & $\begin{array}{c}\text { Полевые } \\
\text { шпаты }\end{array}$ & $\begin{array}{l}\text { Биотит и } \\
\text { мусковит }\end{array}$ & Карбонаты \\
\hline E & हो. & \multicolumn{4}{|c|}{$\%$} \\
\hline
\end{tabular}

\begin{tabular}{|c|c|c|c|c|c|}
\hline$\cong$ & $\begin{array}{l}1 \\
2 \\
3 \\
4 \\
5 \\
6 \\
7\end{array}$ & $\begin{array}{l}89,9 \\
88,0 \\
87,5 \\
80,4 \\
81,9 \\
86,5 \\
74,2\end{array}$ & $\begin{array}{r}7,1 \\
10,7 \\
10,5 \\
15,5 \\
10,0 \\
11,7 \\
9,2\end{array}$ & $\begin{array}{l}0,2 \\
0,3 \\
0,7 \\
1,5 \\
2,9 \\
1,0 \\
0,1\end{array}$ & $\begin{array}{r}2,8 \\
1,0 \\
1,3 \\
2,6 \\
5,2 \\
0,8 \\
16,5\end{array}$ \\
\hline 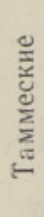 & $\begin{array}{r}8 \\
9 \\
10 \\
11 \\
12 \\
13 \\
14\end{array}$ & $\begin{array}{l}76,7 \\
80,2 \\
80,0 \\
85,1 \\
84,9 \\
84,3 \\
82,7\end{array}$ & $\begin{array}{r}5,8 \\
13,4 \\
15,9 \\
13,7 \\
13,5 \\
13,7 \\
16,3\end{array}$ & $\begin{array}{l}0,5 \\
1,2 \\
0,5 \\
0,2 \\
0,1 \\
0,1 \\
0,4\end{array}$ & $\begin{array}{r}15,7 \\
5,2 \\
3,6 \\
1,6 \\
1,5 \\
1,9 \\
0,6\end{array}$ \\
\hline
\end{tabular}

В химическом составе песчаников отмечены (в процентах):

$$
\begin{array}{r}
\mathrm{CaO}-14,70 \\
\mathrm{MgO}-9,65 \\
\text { нерастворимый остаток }-53,26 .
\end{array}
$$

Почти во всех скважинах песчаники таммеской пачки содержат большое количество молочно-белых известковых псевдоолитов диаметром около 0,5 мм. К ним обычно приурочены и трохилиски.

Мощность песчаников таммеской пачки довольно выдержанная. Она составляет (в метрах):

$$
\begin{array}{r}
\text { Тийрикоя - } 6,4 \\
\text { Муствээ II - } 5,3 \\
\text { Халлику - } 9,05 \\
\text { Хаавакиви - } 10,55 \\
\text { Сааре II - } 8,3 \\
\text { Пала - } 7,9 .
\end{array}
$$

Қак видно из приведенных данных, наблюдается некоторое увеличение мощности в южном направлении.

Разрез пярнуского горизонта венчается маломощными карбонатными отложениями, установленными в скважине Тийрикоя и почти во всех скважинах юго-восточной части Эстонии, где эти отложения представлены водорослевыми доломитизированными известняками, обогащенными буро-коричневым органическим веществом, переслаивающимися с темно-серыми глинами, микрозернистыми доломитизированными желтовато-серыми тонкослоистыми известняками и буровато-серыми алевролитами. Мощность их от 0,2 (Отепя) до 16 м (Палу) (Каяк, 1962; Марк, Паасикиви, 1960).

Определенный интерес представляет разрез верхов пярнуского горизонта в самой северной части выхода девона у Тийрикоя. Здесь на светло-серых кварцевых песчаниках таммеской пачки залегают (снизу вверх) : 
0,40 ж - переслаивание известняка песчано-глинистого и кварцевого песчаника с известково-глинистым цементом. Мощность прослоев от 2 до $5 \mathrm{~cm}$. Известняк обладает желтовато-белой окраской и микрозернистой структурой. Пе :чаник характеризуется серой окраской, мелкозернистостью, слабо окатанными зернами. Поверхности наслоения неровные, извилистые, фиксируются каемками буровато-коричневой окраски.

0,10 - доломит глинистый, в некоторых прослоях песчаный, микрозернистый, тонкополосчатый; тонкополосчатая текстура обусловлена переслаиванием очень тонких (от 1 мм до $1 \mathrm{~cm}$ ) прослоев различного состава (доломита глинистого и песчаного, мергеля) различной окраски (бежевой, светло-серой, серой, коричнево-красной). Встречаются редкие мелкие каверны, вокруг которых развиты гидроокислы железа коричневого цвета.

0,12 м известняк оолитовый, песчаный, светло-серого, почти белого цвета, местами с розовым оттенком. Встречаются небольшие удлиненные горизонтально вытянутые включения глинистого песчаного известняка, а также зеленые зерна глауконита.

0,03 м - доломит светло-серого, почти белого цвета с зеленоватым оттенком, скрытокристаллический, слабо глинистый.

$0,05 \mu-$ известняк оолитовый, светло-серого, почти белого цвета, состоящий на $75 \%$ из молочно-белых кальцитовых оолитов диаметром $0,3-0,44$ мм, имеющих сферически скорлупчатое строение. Часто ядром оолитов являются кварцевые песчинки. Цементируются оолиты известковым цементом.

Оолитовые известняки перекрываются осадочной брекчией наровского горнзонта.

В остальных разрезах на рассматриваемой территории данные отложения не были встречены. Карбонатные отложения, венчающие разрез пярнуского горизонта, вновь встречаются уже в более южных районах (Ныва, Каагвере, Киома, Отепя, Палу, Вяймела), где в отличие от разреза Тийрикоя в них отсутствуют оолитовые известняки.

Наличие отложений пярнуского горизонта на западном побережье оз. Пейпси указывает на их широкое распространение во всей Южной Эстонии от берегов Рижского залива до названного озера. Можно предполагать, что отложения пярнуского горизонта сохранились местами и в Северо-Восточной Эстонии на площади распространения среднедевонских пород, где их наличия можно ожидать в пониженных частях рельефа додевонского ложа.

Генетически отложения пярнуского горизонта Восточной Эстонии представляют собой континентальные осадки (главным образом отложения текучих вод), перемежающиеся прибрежно-морскими отложениями. Об этом свидетельствует наличие двух типов косой слоистости - диагональной и тонковолнистой, а также наличие маломощных прослоев карбонатных пород. Образовались отложения пярнуского горизонта в условиях постепенного опускания территории. К концу пярнуского времени континентальные условия, по-видимому, полностью сменились прибрежно-морскими. Результатом этого явилось почти повсеместное отложение карбонатных пород, венчающих разрез пярнуского горизонта.

\section{ЛИТЕР А Т Р А}

В и йдинг Х. А., 1962, Некоторые данные о минералогическом составе песчаников среднего девона Эстонии, Тр. Ин-та геол. АН ЭССР, 10.

К а я К К. Ф., 1962, К геологии Юго-Восточной Эстонии (по данным глубокого бурения), Тр. Ин-та геол. АН ЭССР, 10.

Марк Э. Ю. и Па аси и и и Л. Б., 1960, Девонская система, Кн. Геология СССР, T. XXVIII, M. 
Селиванова В. А. и Элькин О. Н., 1956, Объяснительная записка к геологической карте СССР, $M$.

O rviku K., 1930, Keskdevoni pōhikihid Eestis, Acta Univ. Tartuensis, A 16.

T a m m e A., 1960, Pärnu lademe liivakivide granulomeetriast ja mineraloogiast Häädemeeste, Tahkuranna ja Tamme puursüdamike ning paljandite pōhjal, ENSV TA Loodusuurijate Seltsi Aastaraamat, kd. 53, Tartu.

Ннститут геологии

Академии наук Эстонской ССР

Поступила в редакцию 30/IX 1966

\section{KORVEL, N. KORVEL}

\section{PÄRNU LADEME LITOLOOGILISEST ISELOOMUST MUSTVEE-PALA UMBRUSES EESTI NSV-S}

Uurides pärnu lademe kivimeid Mustvee-Pala ümbruses 11 puuraugus (joon. 1) selgus, et pärnu lade levib märksa laialdasemal alal, kui seda seni on arvatud. Litoloogiliselt on vōimalik eristada pōhiliselt kahte kihistikku: tori ja tamme kihistik (joon. 2)

Tori kihistikku uuritud alal iseloomustavad karbonaatsete kivimite purdosakestest koosnev pōhikonglomeraat ja bretša, oligomiktilised liivad ja liivakivid, aleuriidid ja aleuroliidid ja ainult kohati - karbonaatsed kivimid. Kihistiku paksus kōigub 5$29,2 \mathrm{~m}$ piires.

Tamme kihistikus esinevad põhiliselt liivad ja liivakivid, vähemal määral leidub graveliitseid (kihistiku allosas), aleuriitseid, savikaid ja karbonaatseid kivimeid (kihistiku ülaosas). Vōrreldes tori kihistikuga, on päevakivide, apatiidi- ja titaniidisisaldus oligomiktilistes liivades ja liivakivides suurem. Tamme kihistikule iseloomustavaks tuleb pidada trohhiliskide ja valgete ooidide esinemist. Kihistiku paksus kõigub 5,3$10,55 \mathrm{~m}$ piires.

Pärnu lademe kōige ülemisemat osa iseloomustab karbonaatsete, savikate ja liivakate kivimite vaheldus. Esinevad ooidid. Kompleksi paksus on $0,70 \mathrm{~m}$.

Arvestades pärnu lademe kivimite litoloogiat, tuleks neid kivimeid pidada kontinentaalseis tingimustes tekkinuiks, mida ainult ajuti asendasid rannalähedase mere tingimused.

\section{KORVEL, N. KORVEL}

\section{ON THE LITHOLOGICAL CHARACTER OF THE PÄRNU STAGE IN THE SURROUNDINGS OF MUSTVEE-PALA, ESTONIAN SSR}

On the basis of a study of the rocks of the Pärnu Stage in 11 boreholes in the surroundings of Mustvee-Pala (fig. 1) it was stated that the Pärnu Stage is distributed over a much wider area than it had been supposed hitherto. Lithologically, it is possible to distinguish two members: the Tori and Tamme members (fig. 2).

The Tori member on the area studied is characterized by basal conglomerate and breccia consisting of rubble particles of carbonaceous rocks, of oligomikt sands and sandstones, aleurites and aleurolites, and only in places by carbonaceous rocks. The thickness of the member fluctuates within the limits of $5-29.2 \mathrm{~m}$.

The Tamme member consists mainly of sands and sandstones, and to a smaller extent of gravelitic (in the lower part of the member), aleuritic clayey and carbonaceous rocks (in the upper part of the member). In comparison with the Tori member, the content of heliolite, apatite and titanite in the oligomikt sands and sandstones is larger in the Tamme member. The characteristic feature of the Tamme member is the occurrence of trochiliscial and white oölites. The thickness of the member fluctuates within the range of $5.3-10.55 \mathrm{~m}$.

The, uppermost part of the Pärnu stage is characterized by an interchange of carbonaceous clayey and sandy rocks. Oölites occur there as well. The thickness of the complex is $0.70 \mathrm{~m}$.

Considering the lithology of the Pärnu stage, those rocks must have been formed in a continental environment which was but rarely replaced by a near-shore environment. 